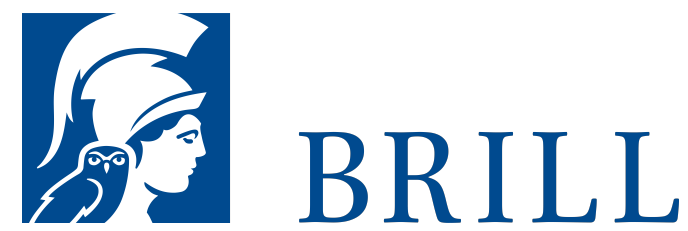

\title{
Doppelagent Heinz Felfe entdeckt Amerika
}

Der BND, die CIA und eine geheime Reise im Jahr 1956

Authors: Bodo Hechelhammer and Bodo V. Hechelhammer

Im Herbst 1956 besuchten BND-Mitarbeiter auf Einladung der CIA die USA. Über mehrere Wochen bereisten sie das Land von der West- bis zur Ostküste, um die amerikanische Kultur besser kennenzulernen. Doch in der Reisegruppe befand sich unerkannt auch ein KGB-Spion: Heinz Felfe. Er entdeckte Amerika im Auftrag Moskaus.

Seit Anfang der fünfziger Jahre organisierte die CIA für handverlesene westdeutsche Geheimdienstmitarbeiter Rundreisen durch die USA. Hinter dem Programm stand die Überlegung, den Teilnehmern die Größe und Vielfalt, vor allem aber die politische, technologische und wirtschaftliche Überlegenheit des Landes vor Augen zu führen. Erstmalig zeichnet der Autor anhand von unveröffentlichten Originalfotos und Reisenotizen detailliert eine dieser Reisen nach. Die Lektüre der Dokumentation ist deshalb so spannend, weil wir mit unserem heutigen Wissen dem Agenten Felfe über die Schulter schauen können. Jahre später wurde er als Spion im BND enttarnt, was den wohl größten Geheimdienst-Skandal in der Geschichte des BND auslöste. Seine Amerika-Reise sollte dabei eine entscheidende Rolle spielen. Bodo Hechelhammer, ChefHistoriker des BND, und sein US-Kollege Kevin C. Ruffner ordnen das damalige Geschehen ein und zeigen, welche Rätsel bis heute weiterbestehen.

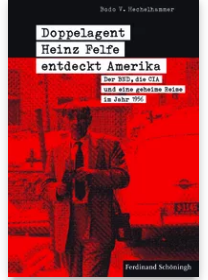

Pages: 256

Seiten, $187 \mathrm{~s} / \mathrm{w}$

Abb.

Language:

German

Subjects:

Contemporary

History, History

Publisher: Brill |

Schöningh

E-Book (PDF)

Released online:

23 Oct 2017

ISBN: 978-3-

657-78694-7

List price

Hardback

Publication date: o8 Sep 2017

ISBN: 978-3506-78694-4

List price 
Biographical Note

Bodo V. Hechelhammer ist promovierter Historiker, hauptamtlicher Mitarbeiter und Chef-Historiker des BND.

For more information see brill.com

\begin{abstract}
Order information: Order online at brill.com +44330 333 0049 | customerservices@brill.com Submission information: brill.com/authors
\end{abstract}

Titles published by Brill | Fink, Brill | mentis or Brill | Schöningh: +49(o)71 5413279216 | brill@brocom.de 